\title{
A Mixed Method Inquiry of Gas Flaring Consequences, Mitigation Strategies and Policy Implication for Environmental Sustainability in Nigeria
}

\author{
Olayemi Hafeez RUFAI ${ }^{1 *} \quad$ Richard Oluwole ALADEMOMI ${ }^{1} \quad$ Emmanuel Tetteh TEYE $^{1}$ \\ Helen Agbornso ASHU ${ }^{1} \quad$ Fat-hiya Abdulla SAID $^{1} \quad$ Victoria Omoladun OLUDU $^{2} \quad$ Ren CHONG $^{1}$ \\ 1.School of Public Affairs, University of Science and Technology of China, Hefei, Anhui, China \\ 2. School of management, Department of Business Administration, Hefei University of Technology
}

Acknowledgement: We are grateful to Professor Ren Chong for providing helpful comments on an earlier draft of this paper and warm appreciation to the Chinese Government Scholarship Council for providing the

Corresponding Author with fully funded study grants to pursue his postgraduate studies at the University of

Science and Technology of China (USTC).

\begin{abstract}
The issue of gas flaring in Nigeria has become a topical one in view of the devastating effect it has in the socioeconomic lives of the people in the affected areas. This paper investigates the environmental implication and mitigating strategies of the victims in Nigeria. Mix method was adopted by conducting 60 semi-structured interviews in three communities. The data was transcribed and analyzed using ATLAS.ti and content analysis. Findings show that gas flaring is the major problem facing the Niger Delta communities having negative effects on resident's health, source of income and farm produce without any legal framework to curb it. Findings also show that people mitigate by using self-strategies such as nose mask, fertilizer for farm produce and boiling of drinking water. Data collected from government shows that there is an annual increase in gas production but gas flaring decreases at a slower rate as depicted in the graph. The paper is the first to conduct research on the coping strategy of the victims of gas flaring in Niger Delta and the importance of technology in eradicating gas flaring. The study recommended technology transfer from technologically advanced countries in capturing the associated gas instead of flaring it.
\end{abstract}

Keywords: Gas flaring, Environmental legislation, Health, Ecological Sustainability, Mitigating Strategy, Government.

DOI: $10.7176 / \mathrm{JEES} / 9-2-07$

\section{Introduction}

Natural gas refining systems entails chemical engineering procedures as well as other installations method used to convert crude oil to be useful for other products such as petrol, kerosene, and Liquefied Petroleum gas (LPG) and jet fuel. Oil and gas is seen as a blessing to countries endowed in such natural resources. However, it can also be a curse if not properly harnessed, especially with the problems associated with gas flaring such as environmental pollution. Nigeria is the richest oil producing country in Africa (Maduka \& Tobin-west, 2017) and possesses abundance of natural gas deposit positing it as the 9th most producing oil and gas country in the world (Abam \& Nwankwojike, 2014; Hassan \& Kouhy, 2013). The country has 182 trillion cubic feet (CF) gas reserve making it the tenth largest globally (Giwa, Layeni, Nwaokocha, Musedik, \& Layeni, 2017) and three times larger than the crude oil reserve of 28.2 billion barrels. In addition, (John, 2012) estimated the daily natural gas production in Nigeria to be 5.78 meters cubic feet of which as large as $80 \%$ is flared, $12 \%$ re-injected leaving as little as $8 \%$ for domestic, industrial, and export markets in 2008. Although gas is richer and cleaner than oil in terms of energy, it is still under explored in Nigeria. A large quantity of associated gas is discarded in Nigeria through a method referred to as flaring or venting (Hassan \& Kouhy, 2013). This is the practice of burning off the associated gas that is produced alongside with oil instead of putting it to market for economic benefit or re-injecting into the ground. Flaring was once globally common, but in more recent times, it has largely been limited to places like Russia, Iran, Iraq, Algeria and Nigeria (Nwaoha \& Wood, 2014). As evidenced in fig. 1 below, global natural gas flaring exceeds 120 billion cubic meters $\left(\mathrm{m}^{3}\right)$ (World Bank, 2015). According to NNPC estimation, 40\% of Nigeria's gas production is wasted through flaring which is equivalent to almost $12 \%$ of annual global flaring (NNPC, 2017) making an economic loss of $\$ 2.5$ billion on a yearly basis as a result of gas flaring (Abam \& Nwankwojike, 2014). This amount of flaring produces approximately 281 million tons of $\mathrm{CO}_{2}$ emissions annually which also contribute to greenhouse gas emission and climate change (Anomohanran, 2012). The negative environmental pollution of gas flaring in Nigeria is alarming, generating global attention. According to (Hassan \& Kouhy, 2013), gas flaring negatively impacts the environment through emission of methane and some chemical component called benzene. The effect can be seen on lack of plant growth and wild animals' disappearance. Researchers prove that the closer the farm to a flaring site, the more tendency crops will be damaged (Hassan \& Kouhy, 2013). Drinking water, rivers and lakes have been polluted in the Niger delta area as a result of gas flaring (Nwankwo \& Ogagarue, 2011) 
and (Maduka \& Tobin-west, 2017) in their findings; show that the people are exposed to hypertension and other non-communicable diseases as a result of gas flaring.

Nigeria has been faced with the problem of how best to harness the flared gas and use it to generate energy to serve the populace. According to (Sahnoune, Belhamel, \& Zelmat, 2016), the importance of energy sector to industrial growth of any country cannot be overemphasized. Industries operate at their full potential when there is constant energy because it is the fundamental basis of infrastructure and attainment of sustainable economic growth.

Energy generation and supply have been a major problem affecting the economic growth of Nigeria. A number of policies have been made to explore gas as an alternative measure to Electricity generation in the country since Nigeria depend largely on hydropower generation (Kainji dam, Jebba) which is producing few Megawatts to about 180 million people and many industrial environments but with a negative outcome. The role multinational oil companies played in the oil and gas exploration in the Niger-Delta has proven to be highly controversial because of gas flaring activities (Umukoro \& Ismail, 2017). However, some efforts have been made by these companies in eradicating gas flared but the effect still remained pronounced in the society.

The sensitivity of the environment and concerns on the matter of sustainable development on gas flaring have gained the attention of world leaders, policy makers and researchers. A number of researchers (Colombo, Barbieri, \& Brambilla, 2016; Ma et al., 2016; Sahnoune et al., 2016; Soltanieh, Zohrabian, \& Javad, 2016; Zolfaghari, Pirouzfar, \& Sakhaeinia, 2017) have identified lack of infrastructure, remote production site and safety and operation as some of the core reasons for gas flaring. In 2011, total gas flared in the world amounted to over 120 billion cubic meters (BCM) (Soltanieh et al., 2016). In the same year, Nigeria's total gas flared amounted to 15 billion which is the second highest gas flaring country in the world after Russia (see figure 1).

Fig 1: Countries and their level of gas flaring

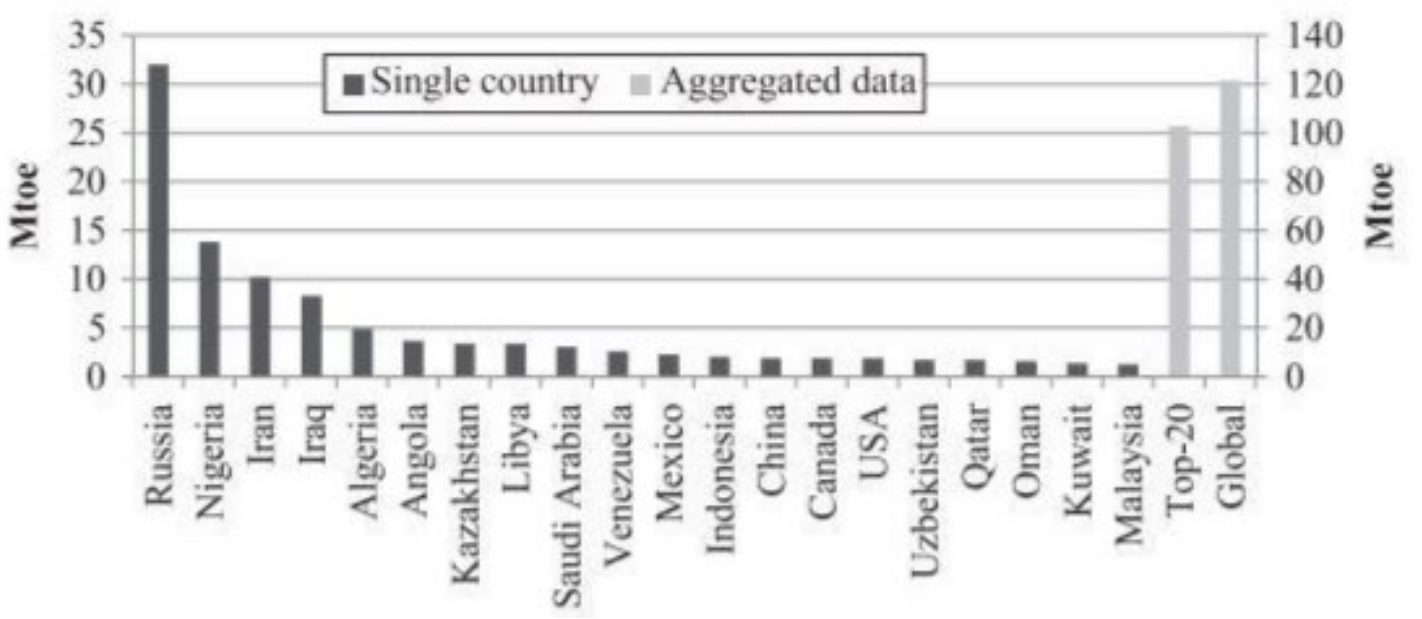

Source: World Bank Report 2015

Even though Kyoto protocol on climate change has enforced countries to indulge in sustainability activities to find a solution to the problem, there is no sign of reduction of gas flaring in Nigeria and it also expose the Nigerian Populace to environmental and health hazard. Countries like Norway, Canada, USA, Qatar has reduced flaring drastically. However, gas flaring has become a significant challenge in Nigeria causing a great environmental, socio-economic and health damage to the wellbeing of the citizens of Niger Delta and also adding to the greenhouse gasses. Mitigating the effects of gas flaring pollution has been the main focus of the Niger Delta citizens as they are concerned more on the long term health effects of the black soot associated to gas flaring which is rampant in their community.

Prior to finding the ways by which the emissions of various pollutions can be reduced, it is of great significance to determine and well analyze the major sources of gas flaring and environmental degradation. Regarding the points that Nigeria remains one of the largest reservoirs of natural gas in the world, the effects of gas wastage into the atmosphere is notable on the people and the environment.

The purpose of this study is to investigate the effectiveness of gas flaring policies and its effect on the socioeconomic, environmental and health of the people of Port Harcourt. The aim is to investigate the coping strategies used by the people and examine the possibility of the recent proclamation by the Nigerian government on ending gas flaring by 2020. This research will be based on both quantitative and qualitative views points and mention the most important factors influencing the flaring process. Focus will be placed on Port Harcourt because it is one of the areas where oil drilling and gas activities are prominent. The rest of this paper provides an overview of the related literature in section 2, research methodology in section 3, followed by results of interview analysis and NNPC data presentation in section 4, discussion of results in section 5 and concluding remarks, recommendation and research limitation in section 6 . 


\subsection{Sources of Gas Flaring}

Gas flaring is the burning of natural gas generated alongside with crude oil in the process of oil and gas extraction while venting is the releasing of unburned gas straight into the climate (Nurbekov \& Putte, 2014). There are various sources of gas such as abundance of the gas extracted which is marketed to other countries in need of it or which may be used domestically. Gas that escaped the tank in the process of filling the tank or gas that is released in the process of doing maintenance or switching of equipment. Gas flaring in some cases can be used for test running of oil well productivity during extraction, and leakage from the pump seal into the climate can also contribute to gas flaring even though the magnitude is little. The highest level of gas flaring, however, is the gas produced as a byproduct from crude oil extraction (Saidi, Siavashi, \& Rahimpour, 2014).

Though oil can be found alone, same as gas but in most cases, both are often found simultaneously in a reservoir (Ma et al., 2016). The gas found alongside with crude oil is known as associated natural gas (ANG). Associated natural gas consisted of blending of hydro carbon whose components include methane, ethane, propane, butane and pentane (Maduka \& Tobin-west, 2017; Wang \& Li, 2018)). Other components are hydrogen sulphide, helium, nitrogen and water vapor. Nigeria possesses abundance resources in both crude oil and gas reserves, but the country's production in gas surpass that of crude oil. According to NNPC (2017), Nigeria crude oil reserves were 28.2 billion barrels whereas natural gas was 182 trillion cubic feet (CF), which shows that Nigeria is three times abundant in gas resources than crude oil.

Another source of gas flaring owed to safety measures in the location of gas production. This requires the release of gas when there is a high pressure from the machineries used for operation. Notwithstanding, the global challenges isn't flaring for safety but rather the inability to invest in gas infrastructures (Evans et al., 2017). However, in Nigeria, oil and gas hardly occur alone which means that for every oil well drilling, there is high tendency of having associated natural gas which increases the level of flaring in Nigeria. Therefore, there is need for urgent remedy and action as it affects the local community and health of the people.

\subsection{Reasons for Gas Flaring}

Gas flaring can occur for three reasons. The first is emergency flaring for safety reason which usually is an impromptu flaring to ease the pressure on the production plants. Secondly, process flaring which occurs as a result of disposing off unwanted gas after production, it goes off in a slow rate and sometimes used in testing the performance of oil well. Thirdly, production flaring which occur in the process of extracting oil and gas from the earth and this is expected to go for a long period of time. Mobility of gas from one place to another is not as easy as that of crude oil (Fawole, Cai, \& Mackenzie, 2016). Normally, gas is expected to be transacted to other buyers in form of fuel or petrochemical feedstock but this will require all necessary infrastructural facilities to be in place such as pipeline and markets platform.

In Nigeria, oil revenue constitutes the largest proportion of the foreign earnings with over $75 \%$ of the foreign reserve (World Bank, 2016) thereby requiring political attention. There has been lack of enforcement of proper environmental regulation practices and conflict among various bodies or agencies saddled with the responsibility of controlling and monitoring petroleum extraction and mining (Maduka \& Tobin-west, 2017). Sufficient measures are lacking in the activities of federal environmental rotation agency and the department of petroleum resources to regulate and enforce anti flaring policies.

The profit government generate from oil industry has caused the government to neglect the infrastructure development of gas industry. For example, the first anti gas flaring law that was passed in 1969 termed "regulation 42 of the petroleum drilling and production regulation" indicate a deadline of five years after the beginning of production to notify the minister of any feasibility plan on the usage of any natural gas, otherwise, the erring companies will be fine. As a result, oil companies generated much profit from the low value set as fine by the government because flaring is much cheaper than reinjection of the gas or utilizing it for other resourceful purposes. For example, the government charged N0.50 per million cubic feet (mcf) in the 1979 Associated Gas Reinjection Act for flaring (Adekomaya, Jamiru, Sadiku, Huan, \& Sulaiman, 2016), US\$0.67 in 1998 per mcf and $\$ 3.5$ in the third quarter of 2011. According to CBN report, \$137 million was generated between January 2005 and December 2011 as against the economic loss \$2.5 billion on a yearly basis (Ojijiagwo, Oduoza, \& Emekwuru, 2016).

\section{Gas Flaring Policy Impacts Review in Nigeria}

The first policy that would have ever been made by Nigerian government on gas flaring was the regulation 42 of the petroleum drilling and production act in 1969 which states that that the licensee or lessee shall provide and forward a comprehensive document to the minister showing any feasibility study, program or proposal within five years of commencement of production for the utilization of any natural gas, whether associated with oil or not, which has been discovered in the relevant areas" (NNPC, 2016). The policy did not work as expected as there was not much reduction of gas flaring in the oil and gas area. The policy was replaced by Associated Gas Re-injection Act of 1979 which states that starting from October 1, 1980, all oil and gas companies must submit a detailed proposal of either reinjection of the associated gas or selling it for commercial purpose and thereby making gas 
flaring an illegal activities by 1984 (Hassan \& Kouhy, 2013). The Nigerian government did not strictly implement the 1984 law as a result of economic boom in the oil industry which generates or constitutes the major source of foreign exchange earnings. Rather, another policy was promulgated stating that oil and Gas Company can continue flaring gas that cannot be re-injected or used appropriately for safety reasons but the flaring will be attached with charges. Any company who fails to pay the charges will forfeit its mining permit. The controlled fee set with the policy was N0.50 per thousand cubic feet of gas flared and raised to N10 naira in 1998 which was later raised again to US \$3.50 per thousand cubic feet of gas flared by January 1, 2009 (Abam \& Nwankwojike, 2014). According to the World Bank (2015), Nigeria government generated an annual income of between US \$150,000370,000 from gas flaring charges. The multinational oil and gas companies continued flaring and paying the charges because it's relatively small but, without the consideration of the effect on the citizens. Even though government generate revenue from charges that would have otherwise been lost if there is no flaring or there is infrastructural facilities to capture the associated gas or sell it as commodities, the health and welfare of the people and the environment would have been prioritized. To achieve this, government implemented an incentive strategy to reduce gas flaring as a result of the ineffectiveness of the legislation and policies to stop flaring (NNPC, 2016).

The Associated Gas Framework Agreement (AGFA) is an incentive introduced in 1992 which consists of 3 years tax holiday, integration of investment aimed at diversifying associated gas to other utility resources as part of the oil field development. As a result of this incentive, some investments on gas projects such as Oso condensate project, Escravos gas project, LNG project and West African gas pipeline project was established. In 1998, there was another incentive to promote investment in economic utilization of flared gas and this includes gas project taxes at $30 \%$ and $85 \%$ for projects relating directly to oil projects. Capital expenditures relating to gas projects which are to be charged under petroleum profit tax.

Five to seven years tax holiday, custom duty and VAT exemption on gas related development equipment, $15 \%$ investment capital allowance and interest to be deducted on loans (Hassan \& Kouhy, 2013). In addition, a legislation that prohibits gas flaring from 31st of December, 2012 was promulgated by the policy makers and it states that any oil company that pollutes the environment through flaring without the permission of the government will be charge a fine which shall be equivalent to the value of gas (Fawole et al., 2016). However, this policy was not seen as been justifiable because there is no provision of markets where the associated gas can be sold and also lack of infrastructural facilities to capture the associated natural gas (John, 2012).

With all these policies and regulations made by the Nigerian government to reduce gas flaring and protect the environment, there still exist the problem of gas flaring which cause pollution in Nigeria and has a direct effect on the people and environment. Therefore, this research seeks to study the effect on the people and proffer suggestive strategy for the people to mitigate against it.

\subsection{Environmental and Health Effect of Gas Flaring in Nigeria}

The effects of gas flaring on the environment play a major role in the development of an economy (Anejionu, Ahiarammunnah, \& Nri-ezedi, 2015). Gas flaring contributes to greenhouse gases through methane $\left(\mathrm{CH}_{4}\right)$ and carbon dioxide $\left(\mathrm{CO}_{2}\right)$. The flare pollutes methane and transforms it to $90-98 \% \mathrm{CO}_{2}$ which is directly discharged into the climate (Braide, Nwachukwu, Adeleye, \& Egbadon, 2016).

It is assumed that the global flare emission rate is more than 400 million tons where Nigeria contributes around 45 million tons (Giwa, Nwaokocha, Kuye, \& Adama, 2017). These emissions are consequential for climate change. The table below display Nigeria's $\mathrm{CO}_{2}$ emissions from gas flaring and consumption in Nigeria. 
Table 1: Top 20 flaring countries 2006-2010 (in bcm)

\begin{tabular}{|l|l|l|l|l|l|l|}
\hline Top 20 flaring countries, *bcm & $\mathbf{2 0 0 6}$ & $\mathbf{2 0 0 7}$ & $\mathbf{2 0 0 8}$ & $\mathbf{2 0 0 9}$ & $\mathbf{2 0 1 0}$ & Change from 2009 to 2010 \\
\hline Russia & 50.0 & 52.3 & 42.0 & 46.6 & 35.2 & $(11.4)$ \\
Nigeria & 18.6 & 16.3 & 15.5 & 14.9 & 15.2 & 0.3 \\
Iran & 12.2 & 10.7 & 10.8 & 10.9 & 11.3 & 0.4 \\
Iraq & 7.2 & 6.7 & 7.1 & 8.1 & 9.1 & 1.0 \\
Algeria & 6.4 & 5.6 & 6.2 & 4.9 & 5.4 & 0.5 \\
Angola & 4.0 & 3.5 & 3.5 & 3.4 & 4.1 & 0.7 \\
Kazakhstan & 6.2 & 5.5 & 5.4 & 5.0 & 3.8 & $(1.2)$ \\
Libya & 4.4 & 3.8 & 4.0 & 3.5 & 3.8 & 0.3 \\
Saudi Arabia & 4.2 & 4.2 & 4.3 & 3.9 & 3.7 & $(0.2)$ \\
Venezuela & 2.1 & 2.2 & 2.7 & 2.8 & 2.8 & 0.0 \\
Mexico & 2.1 & 2.7 & 3.6 & 3.0 & 2.5 & $(0.5)$ \\
Indonesia & 3.2 & 2.6 & 2.5 & 2.9 & 2.3 & $(0.6)$ \\
China & 2.9 & 2.6 & 2.5 & 2.4 & 2.1 & $(0.3)$ \\
Canada & 1.7 & 2.0 & 1.9 & 1.8 & 2.1 & 0.3 \\
USA & 2.0 & 2.1 & 2.3 & 2.0 & 2.1 & 0.1 \\
Uzbekistan & 2.9 & 2.1 & 2.7 & 1.7 & 1.9 & 0.2 \\
Qatar & 2.3 & 2.4 & 2.3 & 2.2 & 1.9 & $(0.3)$ \\
Oman & 2.3 & 2.0 & 2.0 & 1.9 & 1.8 & $(0.1)$ \\
Malaysia & 1.9 & 1.8 & 1.9 & 1.9 & 1.5 & $(0.4)$ \\
Egypt & 1.7 & 1.5 & 1.6 & 1.8 & 1.5 & $(0.3)$ \\
Total Top 20 & 138 & 133 & 125 & 126 & 114 & $(12.0)$ \\
Rest of the World & 23 & 21 & 22 & 21 & 20 & $(1.0)$ \\
Global Flaring Level & 162 & 154 & 146 & 147 & 134 & $(13.0)$ \\
\hline Source: World Bank $G \mathrm{a}$
\end{tabular}

Source: World Bank GGFR and NOAA Satellite Data adopted from (Nurbekov \& Putte, 2014) *BCM means billion cubic metres.

Besides $\mathrm{CO}_{2}$ emissions, flaring also discharges more than 200 diagnosed toxins such as carcinogens, metals, sour gas with hydrogen sulphide and nitrogen oxides (Korppoo, 2018). He argues that these emissions components are liable to stay in the atmosphere for a long time. A number of studies have researched the effect of gas flaring on Niger delta environment. Researches argue that gas flaring increases occurrence of acid rain in the Niger delta area (Adewale \& Mustapha, 2015; John, 2012). Another study found that there is concentration of heavy metals in the surface and ground waters (Nwankwo \& Ogagarue, 2011) and people of Niger delta are prone to ecological and bacteria disease as a result of gas flaring (Adekola, Fischbacher-smith, \& Fischbacher-smith, 2017; Maduka \& Tobin-west, 2017). A study by (Ojijiagwo et al., 2016) shows that there is a statistically significant relationship between gas flaring, foreign direct investment and environmental pollution in Niger delta where he found that there is a causal relationship of gas flaring and oil extraction to air, soil and water pollution in Niger delta.

There are many oil wells in Niger delta and the flaring activities done in the environs are not sustainable as it's extremely closer to inhabited houses in the localities. (Ojeh, 2012) in his case study research on Ebedei in Delta State found that gas flaring generate extreme heat which affect the environment thereby affecting the community and threaten the achievement of sustainable development goal.

The health impacts of air pollution spread across a wide area, and those who rely on locally produced food (purchase from the market or produced from their farm) risk contamination. At the global level, the emissions of carbon dioxide and methane from Nigeria's flares make a substantial contribution to climate change and the cost will mainly fall heavily on the poor people. Gas flaring is a barrier against efforts aimed at the human capital development of the Niger delta via disease and related effects such as hypertension (Maduka \& Tobin-west, 2017; Nnabuife, 2013), cancer, blood disorders, asthma and skin diseases (Adewale \& Mustapha, 2015). It's been in existence for about 4 decades. Life expectancy in the Niger delta is markedly lower than what is obtaining elsewhere in Nigeria. This is not surprising because of the toxic elements released regularly into the atmosphere.

In Nigeria, volume of flared gas is published in NNPC statistical report as well as activities surrounding gas production and gas flaring. However, for some technical or economic justification such as location of natural gas, customers' accessibility and readiness to buy, and government energy policies, most of the gas that is flared could not be sold. Therefore, flaring gas as a waste product will be the only alternative. No matter the reasons, there is need for reduction of gas flaring for cleaner environment which will protect the citizen's health and improve the economy. Official report of the Global Gas Flaring Reduction, GGFR (State, 2019) demonstrates that gases flared into the oil groups in Nigeria contain broadly perceived poisons, for example, benzene, which contaminates the air and causes genuine respiratory irritation, asthma and bronchitis. Gas flares have add to corrosive rain, air contamination, water contamination, consumption of the structures, thundering commotion and the exceptional warmth from the flares. They live and work nearby the flares with no assurance. For example, at the drilling stage, 
there is noise pollution, destruction of vegetation, and disposal of drilling wastes as well as heavy equipment. All these activities pollute the air, environment and water which affect the life expectancy rate of the people living in that region.

\subsection{Social and Economic Implication of Gas Flaring in Niger Delta}

Gas flaring has various social economic impacts on the environment and living things. (Ojeh, 2012) observes that the Niger delta has experienced sufferings and neglect from politicians, oil companies, and government officials. These sets of people enjoy the resources generated in that region but leaving scar in the heart of the people living there. Even basic services or enabling environment such as water and sanitation are missing in most of the areas. Maladministration, misappropriation and wrong planning have been a major issue in the region as most of the development initiatives are half completed or not functioning (Adewale \& Mustapha, 2015). People in the region are deprived of good life which is a key indicator of sustainable development goal.

The most paramount factor among the impact of gas flaring in Niger Delta is the elimination of the ozone layer. According to World Bank report in 2017, Nigeria gas flaring polluted the environment more than that of the sub-Sahara African countries combined. Gas flaring accelerates worldwide environmental change and bringing about steady ascent in air temperature along these lines uncovering the earth and people to high force of sun powered radiation, the effects of these environmental hazard incorporate food scarcity, more diseases, corrosive rain, rain consumption of building structures and the continuous impediment of outrageous climate harm as a result of broadly perceived poisons, for example, benzene noticeable all around (Hassan \& Kouhy, 2013). Consequently, the degradation going on in Niger Delta in form of oil spills and gas flaring has further makes the region to be highly vulnerable to the global climate change affecting its potential capacity to development.

Monetarily, gas flaring has ransacked the country of colossal income and foreign exchange. Ongoing report shows that gas flaring when measured fiscally amounted to a yearly monetary loss of about US $\$ 2.5$ billion (Abdulhakeem \& Chinevu, 2014). Gas flaring and other ecological misuse are the real reasons for the Niger-delta catastrophe resulting to pipeline vandalism and kidnapping. The disregard of the locale for a long time by successive governments in Nigeria degenerated into political unrest and military conflict, which started to surge obviously in the late 1990s and got to the peak in 2009 (Obi, 2009).

The loss due to flare is not just measured in terms of the equivalent monetary value of the gas if it were utilized considering the various ways it could be put to use. According to World Bank report in 2017, the opportunity cost of gas flaring is the loss of heating fuel. For associated gas to be used as a heating fuel, it has to be processed. Processing of associated gas is capital intensive; hence, it would cause economic loss such as loss of employment for pipeline installation and maintenance, loss of profit for pipeline companies, loss of employment of workers working at the gas processing plant, loss of employment as third party gas sellers and loss in standard of living for gas consumers.

\section{Study Area}

The oil-rich Nigeria's Niger Delta consists of nine states namely Abia, Akwa-Ibom, Bayelsa, Cross River, Delta, Edo, Imo, Ondo, and Rivers (Figure 2) with over 37 million inhabitants who constitute $22 \%$ of Nigeria's population (Amadin, 2018).

Fig 2: Niger Delta Map

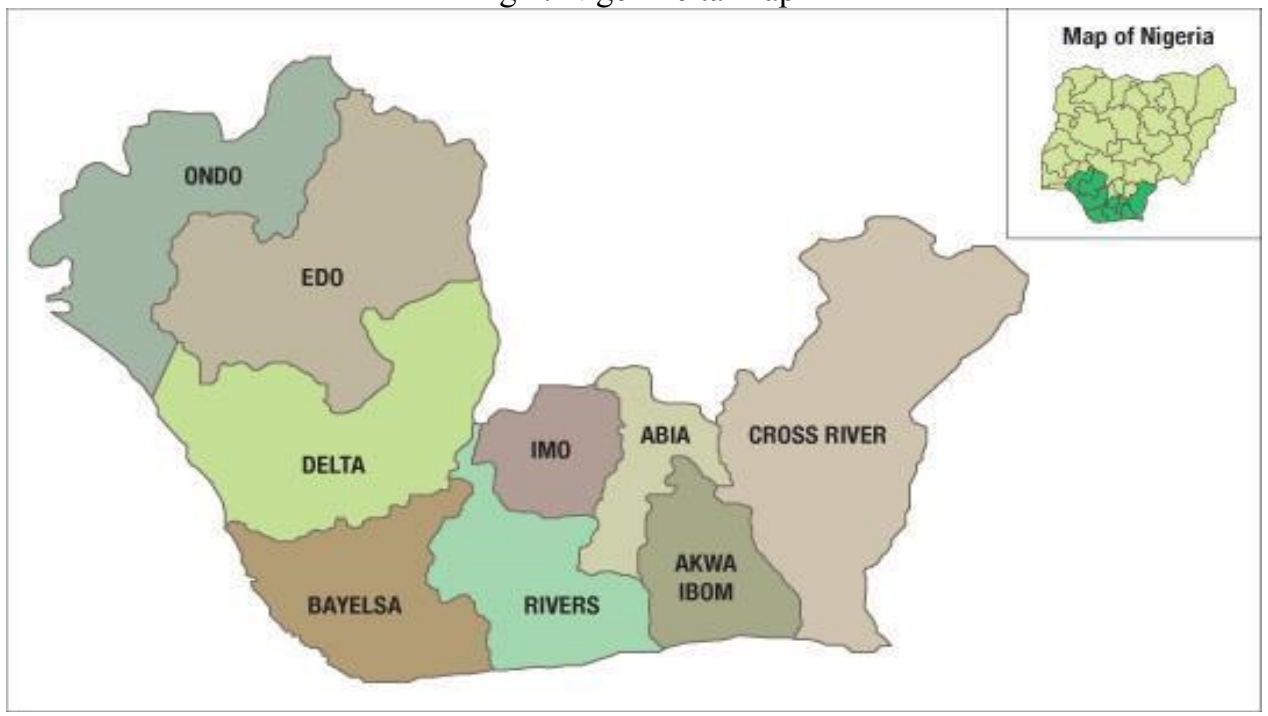

These include more than 1,500 communities that serve as hosts for the oil industry (Adekola et al., 2017). 
The region comprises largely rural communities, but some important Nigerian towns such as Port Harcourt, Warri and Asaba are also included. The inhabitants in the region generally live below the poverty line and rely on fishing and agriculture to survive (Ebegbulem, 2013).

The Niger Delta region is the wealth home that made Nigeria the largest producer of crude oil in Africa and the $6^{\text {th }}$ biggest producer in the world (Bright et al., 2012). Gas flaring and oil spills are frequent phenomenon traced to decay of pipelines, leakages and lack of proper maintenance of infrastructure (Friends of Earth, 2004).

Port Harcourt is a metropolitan city (Ezikorwor, 2018) and capital of Rivers state, occupying approximately $1811.6 \mathrm{~km}^{2}$ area, with a population of about 1.5 million (Johnson \& Gbara, 2012). It is the main city of the state and has one of the biggest seaports in the Niger delta, which is therefore the center of administrative, commercial and industrial activity. Geographical location and topography of Port Harcourt is such that air borne pollutants travel fast and the farthest, as high lands are practically absent. Studies suggest that periodic plumes of pollutants from industrial discharges, a principal source of air pollution, constitutes a frequent occurrence in the city (Ezikorwor, 2018). The study adopted qualitative as well as quantitative data collection methods.

\section{METHODOLOGY}

The study adopted both qualitative and quantitative method of data collection. The study area was drawn from three local government areas Obio-akpor, Khana and Gokana in Port Harcourt, River state.

Table 2: Data collected from three communities visited

\begin{tabular}{|c|c|c|}
\hline S/No & Communities visited & Number of respondents \\
\hline 1 & Obio-akpor community & 25 \\
\hline 2 & Gokana community & 19 \\
\hline 3 & Khana community & 16 \\
\hline Total & & 60 \\
\hline
\end{tabular}

The communities were purposively selected because they are all within oil producing areas that have experienced health risks and environmental damage due to activities of the oil and gas industry such as oil spillage and gas flaring. The populations of these settlements are Obio-akpor (464,789), Khana (294,217), Gokana $(228,828)$. Qualitative data was used in form of semi structured interview because it helps the researcher to know the feelings and perception of the respondents. 80 participants were selected for interview based on convenient sampling method so that it can cut across various professions and the respondents are from the age of 18 years and above. The interview explore two broad areas (1) the socio-demographic characteristics of respondents; (2) their perception of the effect of gas flaring on their socioeconomic wellbeing and environmental and their coping strategies to mitigate against gas flaring.

Quantitative data was collected in form of journals, articles, and government data on gas flaring from Nigerian National Petroleum Commission (NNPC) which was analyzed using trend analysis to examine the status of gas flaring in Nigeria. This is important to compliment the interview carried out from the respondents. We rely on NNPC's ASBs to collect relevant data on oil production, ANG production and the amount of ANG flaring information for the period of 2000-2015. To the best of our knowledge, ASB is the main medium which NNPC reports to the Nigerian public and other interested audiences on the activities of the oil and gas industry.

\subsection{Data Management and Analysis}

With total recourse to ethical considerations addressing issues of privacy and confidentiality, informed consent, and harm to participants (Vanclay et al., 2013), interviews were audio recorded and then transcribed into written form in order to establish the research themes. After several rounds of going through the transcribed data, there was labeling and naming of concepts which led to the development of the research themes in consistence with the research questions. Initial codes developed across the communities and participants include traders, teachers, university students and professionals. It is evident that the people suffered challenges which became worse from the non-involvement or the active participation of the government. Transcripts were read through coded and three themes were identified which are economic status, government involvement and coping strategies used by the community members. Data collected were analyzed using content analysis and discussed in the result and discussion section.

\subsection{Discussions}

From the analysis, three themes emerged after critically examine the coding of the interview response. The first issue involves the economic status of the communities and gas flaring effect. Gas flaring activities has polluted the agricultural system and fishery in the communities which are major source of occupation in the communities.

The second theme was on the role of government involvement in ensuring eradication of gas flaring in the community which was termed nonchalant by the respondents as a result of neglecting from the government to consider the citizens safety first before considering the economic benefit it will make from multinational companies' payment of fine for flaring gas. This according to a respondent was seen not as a fine but as a license 
fee to flare gas and pollute the society.

Another theme identified was the coping strategies used by the communities to survive by themselves. Breathing in polluted air can cause lungs disease and other health challenges (Maduka \& Tobin-west, 2017). Therefore, this involves investigating the method used by the communities to protect their health in the absence of government intervention.

The studies found that over-exploration of oil and gas is contributing to the environmental degradation in Nigeria. Much was also said on the difficulty associated with gas flaring that is currently at the rate of $12 \%$ in Nigeria (NNPC, 2017; Aregbe, 2018). The inadequate infrastructures capable of reinjection of associated natural gas into the ground contribute to the major reasons for flaring gas in Nigeria. It is on record that Nigeria is one of the leading gas flaring countries in the world with high amount of gas resources but low energy because of the lack of investment in converting the flared gas to energy generation. This contributes to the challenges facing economic development of the country (Giwa, Layeni, et al., 2017).

The study affirms previous empirical studies that quiet found that, a number of things are needed to be put in place in order to reduce gas flaring issues as it relates to Nigeria such as access to finance or capital, and the needed policies to control and monitor the activities of the multinational oil and gas companies.

\subsubsection{Responses from Respondents on the Social, Economics, Health and Environmental Impact}

In response to the question 'In what ways has gas flaring have environmental and health effects on the people of your community?' all the 60 respondents pointed to the negative effect caused by oil-related environmental hazards in their community. This seems to be the major source of health appears to be the main source of health issue in the communities and different respondents point to one health challenge or the other such as heartburn, skin diseases, difficulty breathing and eye pain as a result of the effect of gas flaring. Air pollution and contamination of water sources as a result of black soot were identified as posing the greatest health risk due to its effects on everyday water supplies, agricultural outputs and aquatic animals which the communities consume and serve as a source of income. This is in line with studies claiming that gas flares pollute water source, air and negative effect on livelihood of the people (Fawole et al., 2016; Maduka \& Tobin-west, 2017; Nwankwo \& Ogagarue, 2011; Richard \& Ubong, 2009)

Most communities have no energy generation; the light that brightens their night is often the orange color flames from the gas flaring which is the primary cause of acid rain. Unfortunately, most of the communities are without portable water and rely solely on rain water which is the polluted rivers used for domestic and consumption purpose.

\subsubsection{Responses on Government Involvement in Reducing Gas Flaring}

The respondents were asked if they think the government and multinational oil companies are doing something to reduce or eradicate the gas flaring in their community. All the respondents stated that what they got from government is promise and fail, and the agencies saddles with the responsibilities of monitoring the activities of the oil companies engaged in corrupt practices and neglect their primary assignment. These respondents were further asked if the government were doing anything to stop the oil and gas companies from endangering human life with their activities. All the respondents stated that there's high level of greed among the officials in charge of controlling the gas flaring situation. One of the respondents said:

"It's only minimal efforts. Politics and greed has affected their concern for the common man. (Gokana Community). She went further to say that if we were treated good, at least we won't be suffering this way, it has affected our farm product and source of livelihood, there is no much we can do to raise money for ourselves because of pollution and environmental problem".

It was confirmed that none of the government officials or oil and gas companies' representatives have visited the communities to see how they have been coping with the gas flaring effects on their environments.

"As the leader of this community, no one has ever been here among the government officials to check on us and see how we are coping with the situation. NNPC, AGIP, SHELL and others, because they don't care about us. . O Our land, river, and farms have been destroyed such that it's difficult to see any clean water to drink. They have destroyed our land, water, palm trees and streams. The people are not happy but they have no option but to survive on their own. (Khana Community)

Despite representation from the community development council to inform the oil companies operating in the region about the effect of the gas they are flaring, no effort was made to stop the flaring. According to a local youth:

"The oil company shied away from taking responsibility and always give reasons that the flaring was because of much pressure on the reservoir during oil production so as to avoid any disaster within the oil company". (Obioakpor community)

Also no information was given to the community members on how to mitigate the challenges they are facing especially the health implication. Some respondents claimed to have informed the Ministry of Environment but nothing was done either to stop the flaring or to educate the population on the possible health risks they were exposed to. 
A government official interviewed suggested when questioned about one of the incidents that he was always willing to go to the communities and educate the locals but feared for his safety thinking he might even be kidnapped. Apart from being afraid, the official said he may not have the sufficient skills to enlighten the community on how to mitigate against gas flaring because of the high level of illiteracy in the region which may pose a challenge of understanding some scientific terminologies.

\subsubsection{Coping Strategies Used By Community Members}

The study also examined the strategies used by the community's members in mitigation against gas flaring and black soot menace. Some protective measures such as using vinegar to wash vegetables before eating instead of just water are already connected with people's daily life and practices in the communities of the oil and petrochemical installations. Almost $90 \%$ of those interviewed stated that they always boil their drinking water and wash their vegetables because of fear of possible contamination from oil and gas activities.

"This situation is actually difficult to explain because most time people just suddenly noticed that there is some oil particles on the surface of their water which has automatically contaminated the water for drinking and this is as a result of gas flaring and when they drink it they fall sick . . our (community leadership) advice is for them not to even use the water for bathing until the company or government do something." (Obio-Akpor community).

"The pollution is a huge challenge for our community to deal with . . . it affect our rivers and fish . . . we could not fish nor collect water." (Gokana community)

One of the respondents from Khana community reported the frequency of oil exploration related risk incidences such that they have simply stopped worrying about the health implications - most 'residents are now accustomed to the problem' he says, thereby suggesting that the people might have accepted that they must live with the risk and are powerless to effect any change. Some respondents indicated that the best is for them leave the environment and probably relocate to another place that is safe from gas flaring. However, the increase in the population and migration has made land to be scarce and the cost of renting an apartment to be expensive. And also because the source of income (agriculture and fishery) in the communities has been impeded by gas flaring which promotes poverty and makes it difficult for people to be financially well off to relocate.

"Most of we residents drink the water, we are afraid of the possible trouble (implication) it will bring to us, but we have no choice, even we cannot trust the water from the vendors and government don't supply us with water." (Obio-akpor community)

A professor from department of Environmental science in Rivers State University of Science and Technology stated that people have been drinking water without having the scientific facts before them. Some people thought the water was likely to be contaminated but had no choice, others just didn't know it was contaminated because no one has ever told them (Khana community).

It was cleared from the interview that gas flaring activities had a negative impact on the citizen's socioeconomic environmental and health status with the effects including contamination of air, land and water resources by hydrocarbons. However, little was being done to educate or communicate with the public about the health implications of oil exploration activities and possible strategies they could use for mitigation of the gas flaring. There is therefore an urgent need to call on NGOs, environmentalists and social media for continuous awareness creation for the government to take responsibility and drastic measure in strictly implementing policies that will prioritize the welfare of the citizens concerning oil and gas companies activities in the Niger Delta.

Community leaders have reached out for assistance from petroleum organizations for assistance to offset the hardships endured as a result of the natural gas flaring. But oil and gas companies are slow in response which was termed by a respondent as a nonchalant attitude towards the welfare of the people in the communities. Temperaments in the community run rampant when delays are perceived as stalling and avoidance tactics by the petroleum organizations. Therefore, some youths resolve to abductions, social unrest, rioting and criminal activity in order to survive.

\subsection{Findings from NNPC Government Data on Gas Production and Gas Flaring}

The analysis of secondary data is based on documents produced and published by the NNPC and particularly documents related to NNPC's strategy and policies concerning oil and gas production, distribution and flaring. The documents were available online to the public such as annual reports called facts and figures, fact sheet on sustainable community development produced annually. Initial analysis of these documents afforded me the opportunity to obtain background knowledge about the organization's strategy and actions. This was done before conducting interviews. 
Table 3: Gas production and flaring from 2000-2015

\begin{tabular}{|c|c|c|c|}
\hline Years & Gas produced & Gas flared & \% of gas flared \\
\hline 2000 & $1,598,950,233$ & $882,760,070$ & 55.2 \\
\hline 2001 & $1,822,922,111$ & $920,905,671$ & 50.51 \\
\hline 2002 & $1,651,591,488$ & $744,108,035$ & 45.05 \\
\hline 2003 & $1,828,541,855$ & $844,978,886$ & 46.21 \\
\hline 2004 & $2,082,283,189$ & $886,540,196$ & 42.58 \\
\hline 2005 & $2,093,628,859$ & $811,315,777$ & 38.75 \\
\hline 2006 & $2,182,432,084$ & $803,661,823$ & 36.82 \\
\hline 2007 & $2,145,649,041$ & $759,688,726$ & 31.45 \\
\hline 2008 & $2,287,547,344$ & $619,398,854$ & 27.68 \\
\hline 2009 & $1,837,278,307$ & $509,351,905$ & 27.72 \\
\hline 2010 & $2,392,838,898$ & $581,568,354$ & 24.3 \\
\hline 2011 & $2,400,402,880$ & $619,032,858$ & 25.79 \\
\hline 2012 & $2,580,165,626$ & $588,666,724$ & 22.82 \\
\hline 2013 & $2,325,137,449$ & $409,311,430$ & 17.6 \\
\hline 2014 & $2,524,268,444$ & $289,600,014$ & 11.47 \\
\hline 2015 & $2,929,852,323$ & $341,372,264$ & 11.65 \\
\hline
\end{tabular}

SOURCE: Nigerian National Petroleum Corporation (NNPC) published in official website of NNPC (http://www.nnpcgroup.com/PublicRelations/OilandGasStatistics/AnnualStatisticsBulletin/MonthlyPerformance. $\underline{\operatorname{aspx}})$

Fig 2:

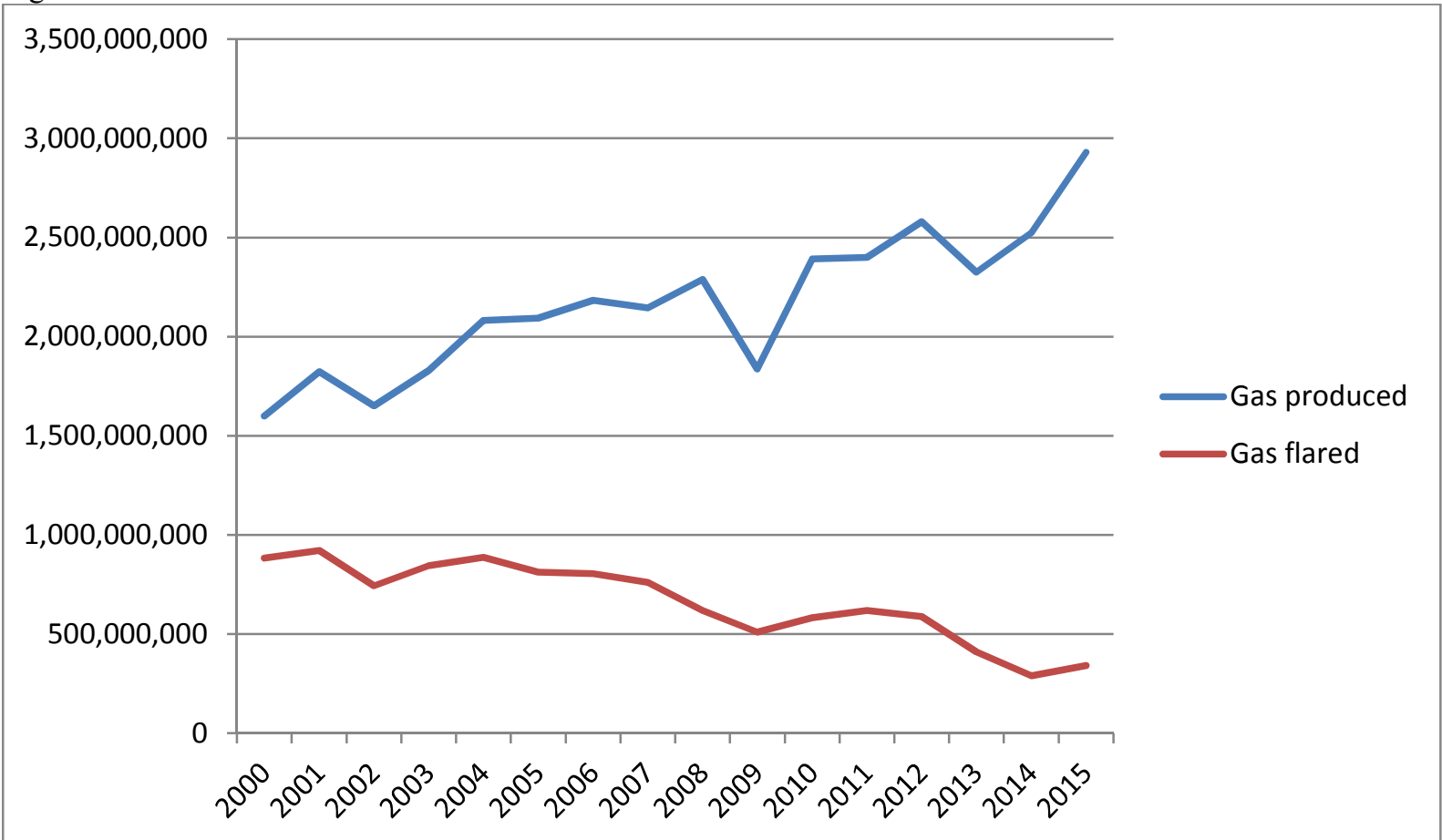

The above Fig and table show the quantity of gas produced and flared over the period of 15 years from year 2000 to 2015 . The findings show that the quantity of gas produced in Nigeria increased systematically from 1.5 billion to 2.9 billion cubic meters within 2000 to 2015, signifying a continuous increase on a yearly basis. This is a result of the abundance of the natural resources in Nigeria. From 2000 to 2007, there was a continuous increase of gas production up to its peak in 2008 before it experiences a sharp decline. The reason for the decline can be traced to the Niger Delta crisis in 2009 where some youths engaged in burning of pipelines which claimed a lot of lives and damage of properties. Global oil price crisis also contribute to the fall in production. Then from 2010, the oil and gas companies stabilized their activities and the production continue rising at an increasing rate. However, over the years, this research found there has been a continuous decline of gas flaring but at a slower rate. This shows that there is still high level of flaring but at a decreasing rate. The current rate of flaring is $12 \%$ (table 3 ). Year 2000 experiences the highest level of gas flared of about $55 \%$ of the total production of the year before it 
started decreasing gradually as a result of some government measures and policies put in place. Ever since Nigeria joined the Kyoto protocol and signed the treaty to reduce environmental pollution in 2012, there has been a constant fall in gas flaring despite the increase in the gas production.

Therefore, this paper posits that considering the table above and interview collected, there is reduction of gas being flared over the years. However, the impact is still being felt on the environment, citizens' health and their socio-economic status. This shows that there is need for government to completely eradicate gas flaring in the region. To achieve, it requires huge amount of capital and infrastructural facilities which can be attained through technology transfer from developed countries whose level of gas flaring and management has reduced drastically (see table 1).

\subsection{Recommendation}

Nigeria's highly abundant in both crude oil and natural gas. However, there is a great negative impact associated with the natural resources endowment. One of such is gas flaring with its attendant effect on environmental degradation, socioeconomic deficiency and contribution to climate change depriving the economy from attaining sustainable development in Nigeria. This research outline following recommendation to the government and policy makers:

1. To preserve the environment and reduce poverty in the region as a result of gas flaring, government should promote foreign direct investment in this area in form of technology transfer to capture the gas flared and convert it to economic benefit such as fuel and feed stock for cement and fertilizer plants, glass manufacturing industries, and food and beverage companies.

2. To embark on a massive awareness campaign in training the affected people in the communities on how to mitigate or protect their health safety against gas flaring.

3. To not only raise the flaring fine presently at $\$ 3.5$, but to also impose heavy penalty and sanction to the erring oil and gas companies. This will enable the oil companies to invest in gas reinjection technology.

4. Instead of flaring the gas, Nigeria government can boost its foreign reserve earnings by exporting the natural gas to some industrialized countries in Asia, North America and Europe.

5. The gas wasted through flaring can also be used for domestic consumption. Many Nigeria households don't have access to gas for cooking because of its scarcity. It will be more beneficial to the populace if the government can promote the activities of the Nigerian Liquefied Natural Gas (NLNG). A company saddled with the responsibilities of harnessing opportunities surrounding natural gas and elimination of gas flaring in the country.

\section{Conclusion}

Gas flaring in Nigeria is as old as the discovery of crude oil in Nigeria. This has become a normal routine despite the harmful to humanity and dangerous to the environment. It has also lead to economic loss to both government and oil and gas companies. Even though there was an effort made from the government to reduce flaring in form of policies and incentives, findings show that these are ineffective because of lack of strict implementation such as allowing the oil companies to continue flaring gas in as much as they can pay the stipulated fine currently of $\$ 3.5$ per cubic feet meter. There is also lack of investment in gas reinjection technologies that can capture the associated natural gas being flared. There must be a concerted effort on the part of the government to end gas flaring in Nigeria in order to safeguard the life of its citizens and promote their wellbeing. The Kyoto agreement of protecting the environment and drastically reducing the amount of carbon dioxide emitted into the atmosphere must be strictly abided if the government wants to achieve sustainable development in the Niger Delta region.

\section{References}

Abam, F. I., \& Nwankwojike, B. N. (2014). Energy resource structure and on-going sustainable development policy in Nigeria : a review. https://doi.org/10.1007/s40095-014-0102-8

Abdulhakeem, S. O., \& Chinevu, A. (2014). Gas Flaring in Nigeria ; Impacts and Remedies.

Adekola, J., Fischbacher-smith, M., \& Fischbacher-smith, D. (2017). Health risks from environmental degradation in the Niger Delta , Nigeria, 35(2), 334-354. https://doi.org/10.1177/0263774X16661720

Adekomaya, O., Jamiru, T., Sadiku, R., Huan, Z., \& Sulaiman, M. (2016). Journal of Natural Gas Science and Engineering Gas $\mathrm{fl}$ aring and its impact on electricity generation in Nigeria, 29. https://doi.org/10.1016/j.jngse.2015.12.042

Adewale, O. O., \& Mustapha, U. (2015). The Impact of Gas Flaring in Nigeria, 3(2), 40-50. https://doi.org/10.11648/j.ijsts.20150302.12

Amadin, F. I. (2018). Conflict Resolution in the Niger Delta Region of Nigeria : An Empirical Investigation, (6), 140-146. https://doi.org/10.30845/ijhss.v8n6p16

Anejionu, O. C. D., Ahiarammunnah, P. N., \& Nri-ezedi, C. J. (2015). Hydrocarbon pollution in the Niger Delta : Geographies of impacts and appraisal of lapses in extant legal framework. Resources Policy, 45, 65-77. 
https://doi.org/10.1016/j.resourpol.2015.03.012

Anomohanran, O. (2012). Determination of greenhouse gas emission resulting from gas flaring activities in Nigeria. Energy Policy, 45, 666-670. https://doi.org/10.1016/j.enpol.2012.03.018

Aregbe, A. G. (2018). Natural Gas Flaring - Alternative Solutions, (February). https://doi.org/10.4236/wjet.2017.51012

Braide, W., Nwachukwu, J., Adeleye, S. A., \& Egbadon, E. O. (2016). Effects of Gas Flaring on the Physicochemical and Microbiological Quality of Water Sources in Egbema , Imo State , Nigeria, 56(2), 713. https://doi.org/10.18052/www.scipress.com/ILNS.56.7

Bright, O., David, E., O, A. J., Bright, O., David, E., \& O, A. J. (2012). Environmental Degredation and Oil Industry Activities in the Niger-Delta Region Environmental Degredation and Oil Industry Activities in the Niger-Delta Region.

Colombo, E., Barbieri, J., \& Brambilla, M. (2016). Alternatives to gas flaring : a multi-criteria decision approach applied to a case study in Russia. International Journal of Sustainable Engineering, 9(3), 154-169. https://doi.org/10.1080/19397038.2015.1050972

Davoudi, M., Rahimpour, M. R., Jokar, S. M., Nikbakht, F., \& Abbasfard, H. (2013). Journal of Natural Gas Science and Engineering The major sources of gas fl aring and air contamination in the natural gas processing plants: A case study. Journal of Natural Gas Science and Engineering, 13(May 1991), 7-19. https://doi.org/10.1016/j.jngse.2013.03.002

Ebegbulem, J. C. (2013). Oil Exploration and Poverty in the Niger Delta Region of Nigeria : A Critical Analysis, 4(3), 279-287.

Evans, M., Kholod, N., Kuklinski, T., Denysenko, A., Smith, S. J., Staniszewski, A., ... Bond, T. C. (2017). Black carbon emissions in Russia: A critical review. Atmospheric Environment, 163, 9-21. https://doi.org/10.1016/j.atmosenv.2017.05.026

Ezikorwor, V. (2018). Urban warming in Port Harcourt metropolis and its environs Urban Warming in Port Harcourt Metropolis and Environs, (April). https://doi.org/10.9734/JGEESI/2018/41123

Fawole, O. G., Cai, X. M., \& Mackenzie, A. R. (2016). Gas flaring and resultant air pollution: A review focusing on black carbon. Environmental Pollution, 216, 182-197. https://doi.org/10.1016/j.envpol.2016.05.075

Giwa, S. O., Layeni, A. T., Nwaokocha, C. N., Musedik, A., \& Layeni, A. T. (2017). Greenhouse gas inventory: A case of gas flaring operations in Nigeria. African Journal of Science, Technology, Innovation and Development, O(0), 1-10. https://doi.org/10.1080/20421338.2017.1312778

Giwa, S. O., Nwaokocha, C. N., Kuye, S. I., \& Adama, K. O. (2017). Journal of King Saud University Engineering Sciences Gas flaring attendant impacts of criteria and particulate pollutants : A case of Niger Delta region of Nigeria. Journal of King Saud University - Engineering Sciences. https://doi.org/10.1016/j.jksues.2017.04.003

Hassan, A., \& Kouhy, R. (2013). Gas flaring in Nigeria: Analysis of changes in its consequent carbon emission and reporting. Accounting Forum, 37(2), 124-134. https://doi.org/10.1016/j.accfor.2013.04.004

John, A. T. (2012). Gas Flaring and its Implication for Environmental Accounting in Nigeria, 4(5), $244-250$. https://doi.org/10.5539/jsd.v4n5p244

Johnson, N., \& Gbara, B. (2012). Population , Environment and Security in Port-Harcourt, 2(1), 1-7.

Korppoo, A. (2018). Russian associated petroleum gas fl aring limits : Interplay of formal and informal institutions, 116(May 2012), 232-241. https://doi.org/10.1016/j.enpol.2018.02.005

Ma, Z., Trevisanut, C., Neagoe, C., Boffito, D. C., Mahdi, S., Jagpal, C., \& Patience, G. S. (2016). A microrefinery to reduce associated natural gas flaring. Sustainable Cities and Society, 27, 116-121. https://doi.org/10.1016/j.scs.2016.06.012

Maduka, O., \& Tobin-west, C. (2017). Is living in a gas-flaring host community associated with being hypertensive ? Evidence from the Niger Delta region of Nigeria, 1-8. https://doi.org/10.1136/bmjgh-2017000413

Nnabuife, J. (2013). Prolonged exposure to oil and gas flares ups the risks for hypertension, 1(3), 65-72. https://doi.org/10.11648/j.ajhr.20130103.15

Nurbekov, A., \& Putte, A. Van De. (2014). An ambitious yet realistic roadmap to virtually eliminate gas flaring and venting in Kazakhstan, 7(6), 499-526. https://doi.org/10.1093/jwelb/jwu021

Nwankwo, C. N., \& Ogagarue, D. O. (2011). Effects of gas flaring on surface and ground waters in Delta State Nigeria, 3(May), 131-136.

Nwaoha, C., \& Wood, D. A. (2014). Journal of Natural Gas Science and Engineering Invited review A review of the utilization and monetization of Nigeria's natural gas resources : Current realities. Journal of Natural Gas Science and Engineering, 18, 412-432. https://doi.org/10.1016/j.jngse.2014.03.019

Obi, C. (2009). Nigeria' s Niger Delta : Understanding the Complex Drivers of Violent Oil-related Conflict, $X X X I V(2), 103-128$.

Ojeh, V. N. (2012). Sustainable Development and Gas Flaring Activities : a Case Study of Ebedei Area of Ukwuani 
LGA, Delta State , Nigeria, 2(4), 169-174. https://doi.org/10.5923/j.re.20120204.06

Ojijiagwo, E., Oduoza, C. F., \& Emekwuru, N. (2016). Engineering Science and Technology , an International Journal Economics of gas to wire technology applied in gas flare management. Engineering Science and Technology, an International Journal, 19(4), 2109-2118. https://doi.org/10.1016/j.jestch.2016.09.012

Richard, G., \& Ubong, I. U. (2009). Health Impact of Gas Flares on Igwuruta / Umuechem Communities in Rivers State.

Sahnoune, F., Belhamel, M., \& Zelmat, M. (2016). Algerian energy policy and potential to reducing greenhouse gas emissions. Energy Sources, Part B: Economics, Planning, and Policy, 11(12), 1118-1127. https://doi.org/10.1080/15567249.2014.936537

Saidi, M., Siavashi, F., \& Rahimpour, M. R. (2014). Journal of Natural Gas Science and Engineering Application of solid oxide fuel cell for fl are gas recovery as a new approach ; a case study for Asalouyeh gas processing plant , Iran. Journal of Natural Gas Science and Engineering, 17, 13-25. https://doi.org/10.1016/j.jngse.2013.12.005

Soltanieh, M., Zohrabian, A., \& Javad, M. (2016). International Journal of Greenhouse Gas Control A review of global gas flaring and venting and impact on the environment : Case study of Iran. International Journal of Greenhouse Gas Control, 49, 488-509. https://doi.org/10.1016/j.ijggc.2016.02.010

State, B. (2019). Nigeria and World Bank Global Gas Flaring Reduction ( GGFR ) Partnership : The Tragedy of the Commons, (September 2015). https://doi.org/10.13140/RG.2.1.2019.6324

Umukoro, G. E., \& Ismail, O. S. (2017). Modelling emissions from natural gas flaring. Journal of King Saud University - Engineering Sciences, 29(2), 178-182. https://doi.org/10.1016/j.jksues.2015.08.001

Vanclay, F., Baines, J. T., Taylor, C. N., Vanclay, F., Baines, J. T., \& Taylor, C. N. (2013). Principles for ethical research involving humans : ethical professional practice in impact assessment Part I. Impact Assessment and Project Appraisal. Taylor \& Francis. https://doi.org/10.1080/14615517.2013.850307

Wang, D., \& Li, T. (2018). Carbon Emission Performance of Independent Oil and Natural Gas Producers in the United States. https://doi.org/10.3390/su10010110

Zolfaghari, M., Pirouzfar, V., \& Sakhaeinia, H. (2017). Technical characterization and economic evaluation of recovery of $\mathrm{fl}$ are gas in various gas-processing plants. Energy, 124, 481-491. https://doi.org/10.1016/j.energy.2017.02.084

World Bank (2015). Report on global gas flaring

http://www.worldbank.org/en/programs/gasflaringreduction 